\title{
Review of Shot-Hole Disease of Stone-Fruit Trees
}

\section{ABDOLLAH AHMADPOUR}

Higher Education Center Shahid Bakeri Miyandoab, Urmia University, Urmia, Iran

(a.ahmadpour@urmia.ac.ir)

Received: 20.11.2017

Accepted: 09.06.2018

Ahmadpour A. 2018. Review of shot-hole disease of stone-fruit trees. Plant Pathology Science 7(2):1-13. DOI: 10.2982/PPS.7.2.1

Abstract: Shot-hole caused by Stigmina carpophila, is an important disease of stone fruit trees worldwide including Iran. The pathogen produces sporodochia bearing sympodial conidiophores, bearing conidia which have often 3-5 cells. Pathogen has wide host range and can infect almost all species of the genus Prunus. The pathogen overwinters as mycelium in twig cankers and blighted buds or in it is associated with dormant buds. Temperature and duration of wetness are important factors on disease incidence and its severity. The pathogen penetrates the plant indirectly through stomata or directly with its appressoria. Because of the importance of shot hole disease in Iran, symptoms, morphological characteristics of the pathogen, epidemiological factors and methods of disease management are discussed in this review.

Key words: Cherry, Peach, Plum, Stigmina

$$
\begin{aligned}
& \text { مرورى بر بيمارى لكه غربالى درختان ميوه هستهدار } \\
& \text { عبداله احمديور } \\
& \text { مركز آموزش عالى شهيد باكرى مياندوآب، دانشخاه اروميه } \\
& \text { دريافت: }
\end{aligned}
$$

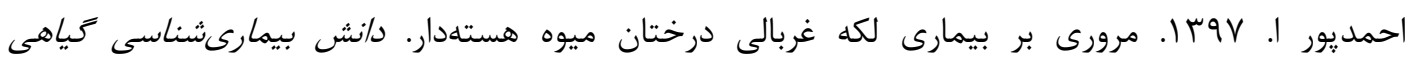

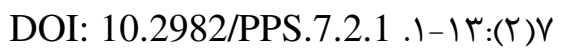

$$
\begin{aligned}
& \text { جكيده: لكه غربالى ناشى از الم Stigmina carpophila يك بيمارى مهم درختان ميوه هستهدار در ايران و جهان } \\
& \text { است. بيماركر اسيورودوكيومهاى با كنيديومبرهاى سميوديال و كنيديومهاى ه-r سلولى توليد مىكند و دامنهى }
\end{aligned}
$$

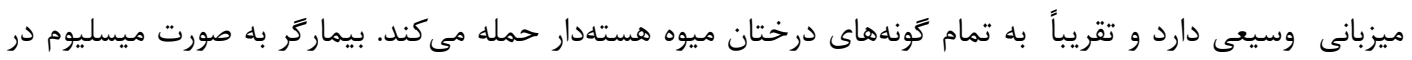

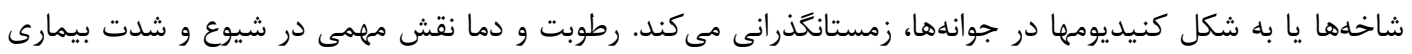

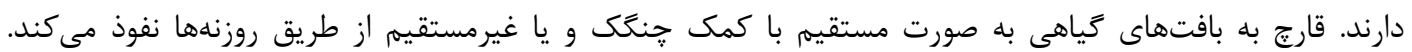

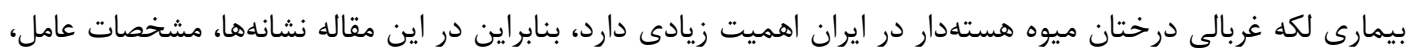

$$
\begin{aligned}
& \text { نحوهى شيوع و روشهاى مديريت بيمارى شرح داده شدهاند. } \\
& \text { وازههاى كليدى: كيلاس، هلو، آلو، Stigmina }
\end{aligned}
$$


كشت درختان ميوه هستهار در نقاط مختلف ايران بخش مهمى از فعاليتهاى باغبانى كشور را به خود

اختصاص داده است و هر سال انواع ميوهها يا فرآوردهاى آنها به مصارف داخل كشور و يا به كشورهاى خارجى صادر مىشود. زيستگاه اصلى برخى گونههاى درختان ميوه هستهدار مانند هلو و بادام ايران است (رادنيا هVI I (آمار دقيقى از تعداد گونههاى درختان ميوه هستهدار اهلى يا وحشى در ايران وجود ندارد. با

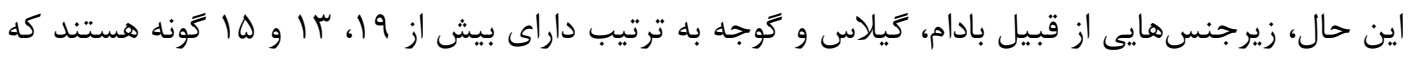
در نقاط مختلف كشور به ويزه در ارتفاعات و كوهستانها انتشار دارند (قهرمان IVVY). طبق آمار منتشر شده از طرف سازمان خوار و بار جهانى (FAO) در سال \& أ ب ميلادى، ايران از نظر ميزان توليد اغلب كونههاى ف درختان ميوه هستهدار در بين ينج كشور عمده توليد كننده جهان قرار دارد. بىشك يكى از مهمترين عواملى كه مىتواند در كاهش عملكرد كونههاى مختلف درختان ميوه هستهدار تأثير گذار باشد، شيوع بيمارىهاى قارجى متنوعى است كه اندامهاى مختلف آنها را تحت تأثير قرار داده و باعث كاهش كمى و كيفى اين كياهان مى عواملى است كه خسارت قابل ملاحظهاى به درختان ميوه هستهدار وارد مى كند. اين بيمارى در اغلب مناطق جهان كزارش شده (Gantina-Ievina and Stanke Ivanová et al. 2012,, Ogawa et al. 1995 2015) ـ ميزان هزينهاى كه هر ساله جهت مبارزه با اين بيمارى در ايالت كاليفرنياى آمريكا صرف مىشود، معادل ها -ه ميليون دلار برآورد شده است (Shaw et al. 1990). بيمارى در سالهاى اخير نيز در برخى از

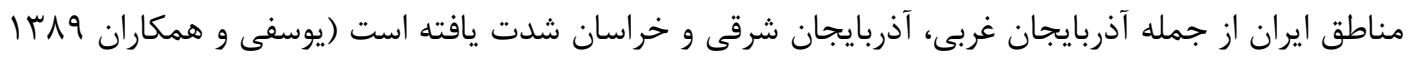

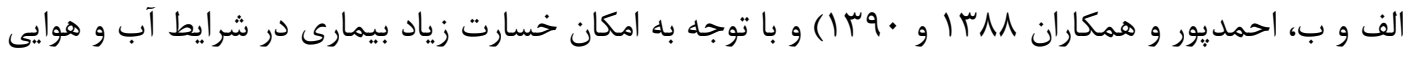
اين مناطق كشور، در اين مقاله به مشخصات ريختى بيمارگر، نحوهى آلودىى و شيوع بيمارى و روشهاى مديريتى بيمارى شرح داده شده است.

\section{- إهميت بيمارى}

بيمارى لكه غربالى يكى از مهمترين و خسارتزاترين بيمارىهاى درختان ميوه هستهدار در اغلب مناطق جهان است. بيمارى لكه غربالى نخستين بار از فرانسه در سال ץ^1ا ميلادى توسط لويله (Léveillé) كَارش 
شده است. سيس از ساير مناطق جهان گزارش شده است. إيدمى شديد بيمارى در ايالت كاليفرنياى آمريكا معمولاً روى درختان بادام در اوايل بهار رخ مىدهد. هزينه مبارزه اين بيمارى در ايالت كاليفرنياى امريكا با سه

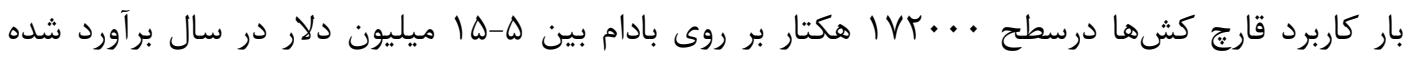
است(Ogawa et al. 1995). اسفنديارى در سال هזrا اين بيمارى را از مازندران، گيلان، گرگان و آذربايجان گزارش كرده است. تاكنون اين بيمارى روى درختان زردآلو، گيلاس، آلبالو، گوجه، هلو، شليل و بادام ديده شده است و خسارت عمدهى آن بيشتر متوجه درختان زردآلو مىباشد و شدت بيمارى در استان هاى آذربايجان غربى و شرقى و خراسان به ويزه در باغهاى قديمى زياد مىباشد (يوسفى و همكاران 91٪1

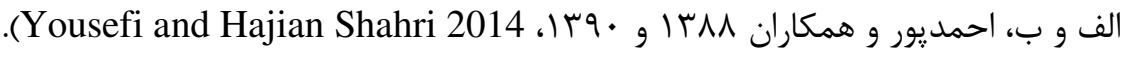

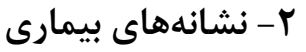

زردآلو، هلو، شليل، كيلاس، بادام، آلو و آلبالو از ميزبانهاى مهمه بيمارى لكه غربالى هستند. سرشاخهها، گَلها، بركَها، ميوهها و جوانهاى درختان فوق مورد حملهى قارج عامل بيمارى قرار مى گيرند. نوع اندامهاى مورد حمله و نشانهاى آنها روى ميزبانهاى مختلف متفاوت مىباشد (شكل (). بيشترين خسارت در زردآلو

Ogawa et al. ) به ميوهها و جوانهها، در هلو به سرشاخها و جوانها و در بادام به بركها وارد مىشود 1995). سوراخ سوراخ شدن برىها و بروز حالت غربالى مشخصترين نشانهاى بيمارى مىباشد. تقريباً ميوههاى همه كَونهاى مختلف هستهدار توسط عامل بيمارى آلوده مىشوند (Ogawa et al. 1995). روى

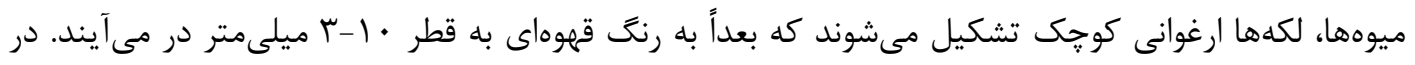
برخى موارد از زخمها صمغ ترشح مىشود (شكل A-F (1). نشانههاى بيمارى لكه غربالى روى سرشاخهها اكثراً به صورت زخم و ترك خوردگى ظاهر مىشوند. معمولاً اندازمى زخمها روى سرشاخهها • ا-ب ميلىمتر است كه اسيورودوكيومها در وسط آنها تشكيل مىشوند. اين حالت بيشتر در هلو و شليل ديده مىشود و در بادام و زردآلو نادر است (شكل H-I (). در طول ماههاى مرطوب زمستان، عامل بيمارى جوانهها را آلوده مى كند و آنها را مىكشد. گاهى اوقات از جوانهاى مرده صمغ ترشح مىشود كه ظاهرى براق دارند. آلودىى شكوفهها

روى گونههاى مختلف هستهدار به جز بادام ديده نمىشود (شكل () (Ogawa et al. 1995). 

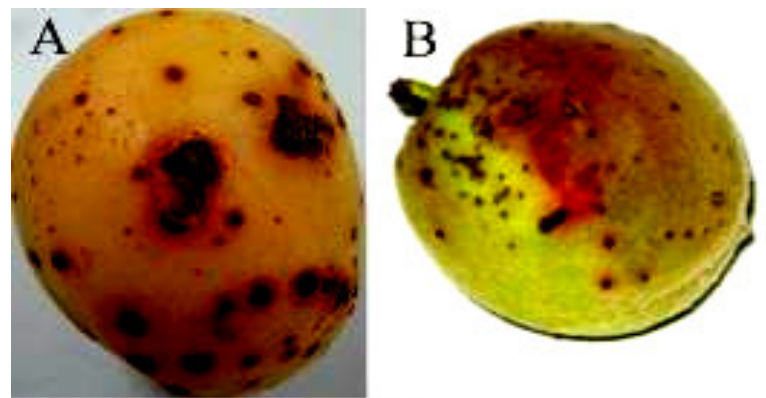

C
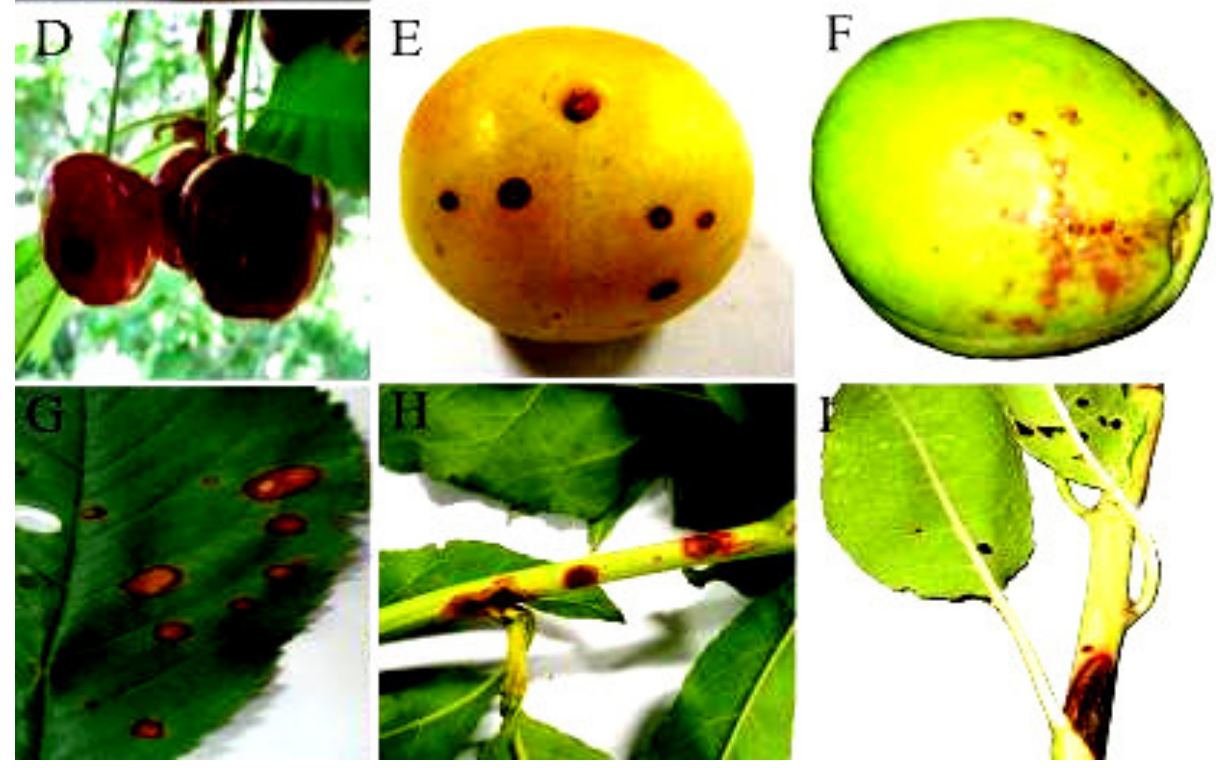

شكل ا- نشانههاى بيمارى لكه غربالى روى ميوهها، بركها و سرشاخههاى گونههاى مختلف هستهدار: (A) ميوه زردآلو B)) ميوه هلو، (C) ميوه بادام، (D) ميوه كيلاس، (E) ميوه آلوجه، (F) ميوه شليل، (G) برى كيلاس، (H) سرشاخه هلو، (I) سرشاخه بادام.

Figure 1. Symptoms of shot hole disease on Prunus spp. fruits, leaves and twigs: (A) Apricot fruit, (B) Peach fruit, (C) Almond fruit, (D) Cherry fruit, (E) Plum fruit, (F) Nectarine fruit, (G) Cherry leaf, (H) Peach twig, (I) Almond twig.

$$
\text { r - عامل بيمارى لكه غربالى درختان ميوه هستهدار }
$$

عامل بيمارى از Stigmina carpophila (Lév.) M.B. Ellis تيرهى Mycosphaerellaceae، راسته Capnodiales ، رده Dothideomycetes، زيرشاخه Pezizomycotina، شاخه Ascomycota است. يركنهى قارج روى محيط PDA و شرايط تاريكى به رنگ زيتونى روشن تا تيره بوده و در حاشيه به رنگ كرمى تا سفيد ديده مىشود. اسيورودوكيومها به صورت نقاط قهوهاى كمرنغ تا تيره، منفرد و يا مجتمع و به ابعاد rV-Ar Hm به فراوانى تشكيل مىشوند. اسيورودوكيومها حاوى كنيديومبرهايى با رشد سميوديال، 


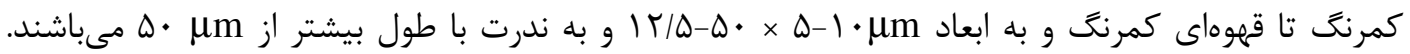
كنيديومبرها داراى ب-1 خميدگى زانويى (geniculate) بوده و زخمها (scars) روى آنها واضح تا ناواضح مى باشند (شكل YA-C). كنيديومها داراى ديوارهى ضخيه بوده و سطحى صاف دارند. كنيديومها دوكى شكل بوده و به صورت منفرد در بخش انتهايى كنيديومبرها تشكيل مىشوند (شكل Y). در مواردى (fusoid) كنيدى ها به اشكال بيضوى يا گرزى هم ديده مىشوند. سلولهاى انتهايى كنيديومها داراى نوك كرد يا تيز

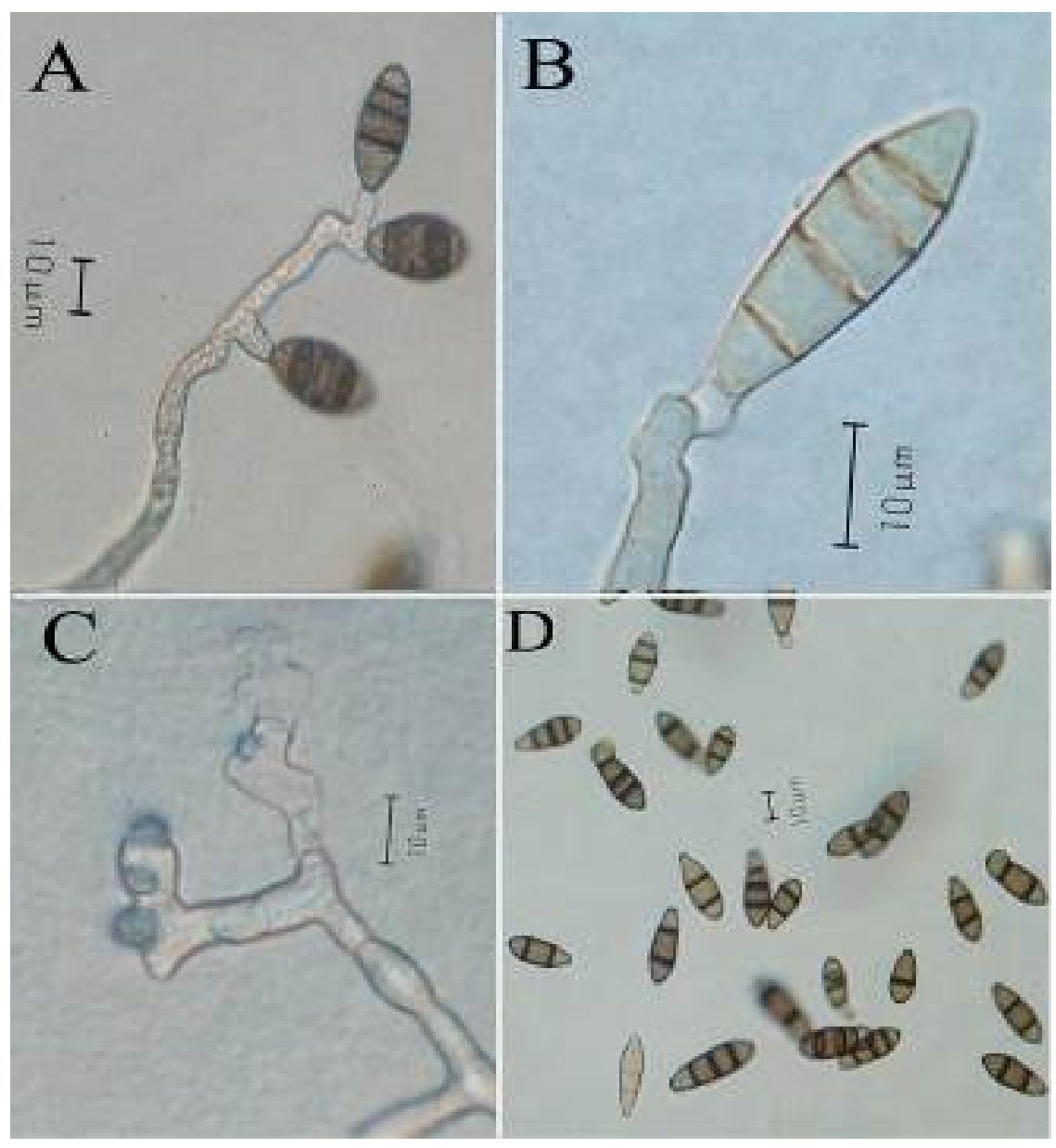

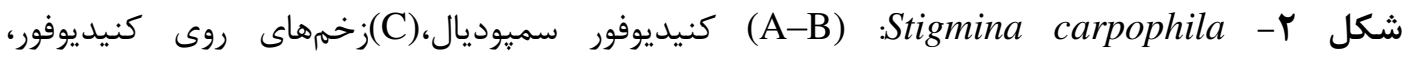

$$
\text { (D) }
$$

Figure 2. Stigmina carpophila: (A-B) Sympodial conidiophore, (C) Scars on conidiophores, (D) Conidia 3-5 cells (Bar= $10 \mu \mathrm{m})$. 
بوده و سلولهاى يايينى در قاعده تخت (truncate) مىباشند. كنيدىها ف-r سلولى (كاها q-ا سلولى) بوده، ابعادآنها M تا قهوهاى كمرنت يا تيره بوده و به ندرت داراى r-1 ديواره عرضى مورب (oblique) هستند (شكل r)

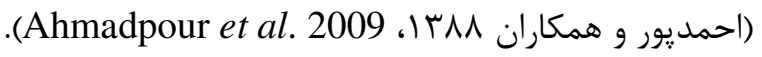

\section{F- جر خهى بيمارى و إيدميولوزى لكه غربالى}

عامل بيمارى لكه غربالى به صورت ميسليوم در زخم شاخهها يا جوانههاى سوخته و به صورت كنيديومها

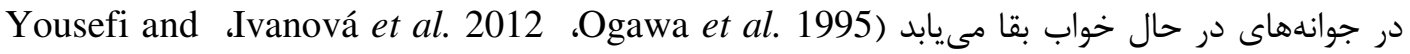
Hajian Shahri 2014 ). كنيديومها به آسانى توسط جريانات باد يراكنده نمىشوند. قطرات آب نقش مهمى در يخش كنيدىها و انتشار بيمارى دارد. ظهور نشانهاى بيمارى بر حسب دما و نوع اندام مورد حمله، If

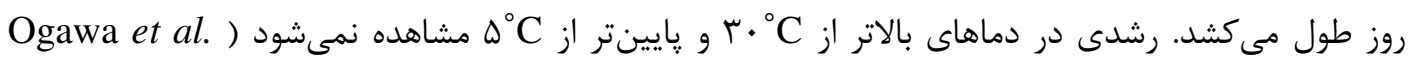
1995). نور نقش مهمى در هاگزايى قارج بازى مى كند (Teviotdale et al. 1997). تعداد زخمها در نهال-

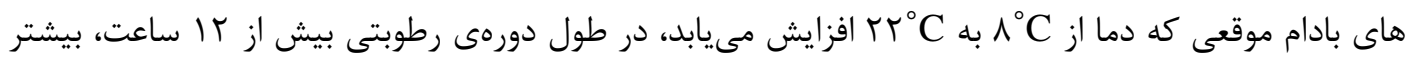
Shaw et (مىشوند. همجنين بر اساس طول مدت رطوبت و دما يك مدل بيشآكاهى بيمارى ابداع شده است al. 1990 . بررسى تأثير دما و رطوبت نسبى در توسعه بيمارى روى درختان هلو و گيلاس نيز نتايج مشابهى به همراه داشته است(Grove 2002). قطرات باران در جدا شدن كنيديومها از جوانها و پخش و انتشار آنها Highberg and Ogawa ( به اندامهاى ديكر درختان و همجنين آلودگى اندامهاى گياهى نقش اساسى دارد

\section{ه- نحوهى جوانهزنى كنيديوم، نفوذ، آلودگى و گسترش بيمارى در بافت تياه}

كنيديومها در مدت جهار ساعت رطوبت، از يك يا تعداد بيشترى از سلولها جوانه مىزنند و لوله تندش لايههاى ديوارمى خارجى آنها را ياره مىكند. در شرايط مرطوب، لولههاى تندش در عرض هشت ساعت ديوارهدار مىشوند و انتهاى آنها تورم پِيدا كرده و تشكيل جنعَك مىدهند (شكل YA-C). نفوذ در بافتهاى سالم بركها به طور غيرمستقيم از طريق روزنهها نيز انجام مى ئيرد (شكل IC) (Adaskaveg et al. 1990، 1995 Adaskaveg). زخمهاى تشكيل شده در برىها در دماى C C T از بافتهاى سالم جدا شده و ظاهرى 
غربال مانند در بركها مشاهده مىشوند (شكل HH). اطراف زخمها لايهى سوبرين- لينخين تشكيل مىشود

كه اين لايه فاقد فضاهاى بينسلولى مىباشد (شكل F-F). اسيورودوكيومها بعد از لها روز در دماى

روى زخمهاى باقيمانده در برگها و يا ريزش كرده تشكيل مىشوند (شكل ॠG). در نهايت كنيديومهاى

تشكيل شده به وسيله باران روى بركها، شاخهها و جوانهها قرار مى گيرند (Adaskaveg et al. 1990،

.(Adaskaveg 1995

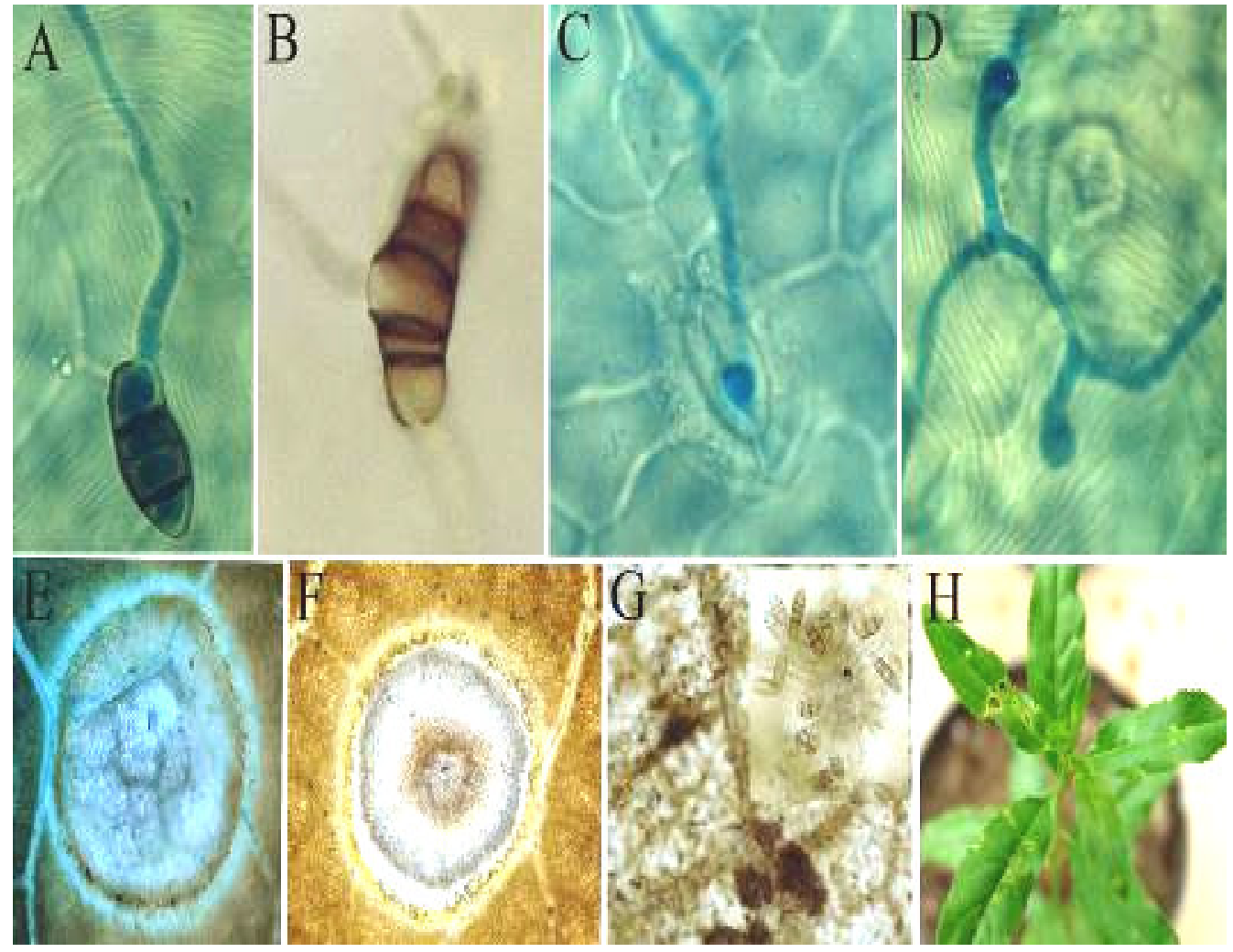

شكل سـ- نحوه جوانهزنى، نفوذ، آلودگى و گسترش بيمارى لكه غربالى روى برگهاى نهالهاى بذرى بادام: جوانهزنى كنيديومها، C(A-B) نفوذ از طريق روزنهها، (D) نفوذ از طريق إيرسوريومها، (E-F) تجزيه بافت اطراف كنيديومها و جدا شدن بافت آلوده از سالم، (G) تشكيل اسيورودوكيومها در سطح رويى بركها،

$$
\text { نشانهاى لكه غربالى روى بركهاى بادام. }
$$

Figure 3. Germination, penetration, infection and colonization of shot hole disease on almond seedling leaves: (A-B) Germination of conidia, (C) Penetration through stomata, (D) Penetration through appressoria, (E-F) Degradation of tissue around conidia and abscission of infected tissue from healthy tissue, (G) Formation of sporodochia on the upper leaf surface, $(\mathrm{H})$ Symptoms of shot hole disease on almond leaves. 


\section{9- دامنهى ميزبانى قارج Stigmina carpophila}

دامنهى ميزبانى قارج بيماركر وسيع است و تقريباً به تمامى كونههاى مختلف درختان ميوه هستهدار حمله مى كند (احمديور و همكاران •وبا، Farr and Rossman 2017 حساسيت كونههاى مختلف درختان ميوه هستهدار نسبت به عامل بيمارى لكه غربالى يكسان نيست و كونهاى Prunus hortulana، Pساسيت شديدى به قارج عامل لكه غربالى دارند. همجنين تعدادى از P. umbellata و P. reverchonii كونههاى هميشهسبز درختان ميوه هستهار تحت شرايط كاليفرنياى آمريكا توسط اين قارج آلوده مىشوند .(Ogawa et al. 1995)

\section{V - مديريت بيمارى لكه غربالى درختان ميوه هستهدار}

مديريت بيمارى از طريق هرس و حذف سرشاخههاى آلوده، استفاده از ارقام مقاوم، سمياشى با سموم محافظتى (تماسى) و استفاده منطقى از كودها صورت مى كيرد. واكنش ها رقم كيلاس نسبت به بيمارى لكه غربالى يكسان نبوده و ارقام Giorgia و Moreau ،Bigarreau ،Starking Hardy Giant حساسترين و ارقام Cerrovia و Celeste ، Sunburst Lapins مقاومترين ارقام بودند(Romanazzi et al. 2005). احمديور و همكاران (••جr|) نيز نشان دادند كه تفاوت معنىدارى بين مقاومت نسبى ارقام هلو و بيمارىزايى جدايهها وجود دارد و رقم ديكسىد حساسترين و ارقام ردتاب، اسبر ينگ كرست و آلبرتاى پيشرس مقاومترين ارقام بودند. نتايج مشابهى نيز در مقاومت ارقام زردآلو (11 رقم) (حاجيان شهرى و همكاران سوب|)،

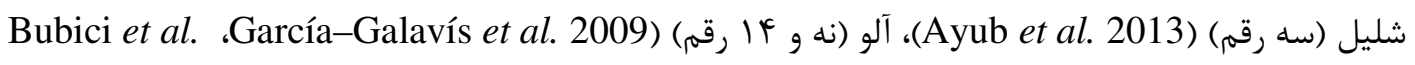
2010) و هلو (ده رقم) (Marcuzzo et al. 2017) به بيمارى لكه غربالى كزارش شده است. براساس اطلاعات موجود اغلب يزوهشهاى انجام شده در خصوص مقاومت ارقام كونههاى مختلف درختان ميوه هستهدار به بيمارى لكه غربالى در دنيا و ايران محدود به آزمايشهاى كلخانهاى، نهالهاى بذرى و سرشاخههاى بريده بودهاند و اين موضوع نياز به مطالعه بيشترى دارد. توليد ارقام مقاوم نيز بدون در نظر كرفتن تغييريذيرى عامل بيمارى، باعث شكسته شدن مقاومت آنها مىكردد (Milgroom 2015, McDonald 1997 ). لذا شناخت ساختار زنتيكى جمعيت بيماركر و آكاهى از جنبههاى مختلف مقاومت از اهميت ويزواى برخوردار است. Ahmadpour et ) RAPD-PCR مطالعه ساختار زنتيكى جمعيت بيماركر با استفاده از روشهاى مولكولى 


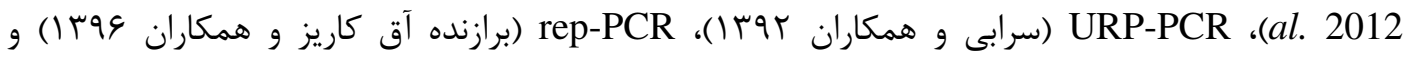
نشان داده كه جمعيت قارج از تنوع زنتيكى بالايى برخوردار مىباشد و (Nabi et al. 2018) ISSR همبستكى بين ميزبان گياهى و منطقه جغرافيايى با دادهاى مولكولى وجود ندارد. با توجه به تنوع زنتيكى بالاى مشاهده شده در جمعيت بيماركر، اهتمام به كشت ارقامى با مقاومت نسبى زياد و زنهاى مقاومت متفاوت مىتواند از شيوع و شدت بيمارى تا حد زيادى جلوكيرى كند. لذا تحقيقات بيشتر در اين زمينه مىتواند در برنامههاى اصلاح نزاد و توليد و تكثير ارقامى با مقاومت نسبى بيشتر در برابر بيمارى لكه غربالى مدنظر قرار گيرد. سمياشى با مخلوط بوردو يا ساير سموم مسى قبل از شروع بارندگى در پاييز مىتواند جوانه و شاخهها را در طول زمستان در مقابل آلودىى محافظت كند. براى جلوگيرى از آلودگى برگها و ميوهها سمياشى در بهار بعد از ريزش كَلبر گها توصيه مىشود. مىتوان از سمومى مانند كايتان، زينب و فربام و يا سم نفوذى ايِروديون Highberg and (Trifunović et al. 2013 Ogawa et al. 1995,) هايبرگ و أُخاوا 9 • نيز نشان دادند كه شدت بيمارى لكه غربالى روى درختان بادام با كاربرد قارجكشها (Ogawa 1986a درصد كاهش يافته و ميزان محصول نيز به ترتيب با كاربرد قارجكشهاى زيرام و كايتان در مرحلهى ريزش

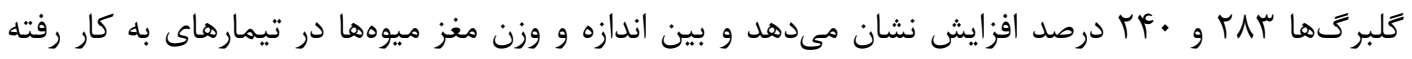
تفاوتى وجود ندارد. نتايج مطالعات خباز جلفايى و همكاران (بوץ|) نيز نشان دادند كه قار جكش جديد ميشو بردوكس ${ }^{\circledR}$ (SC 18\%) كارآيى بيشترى نسبت به سموم ديخر مسى دارد و با دو مرحله سمياشى در آخر پاييز هنگام ريزش برىها و آخر زمستان در مرحله تورم جوانههاى گل بيمارى لكه غربالى به خوبى كنترل مى و نيازى به سمياشىهاى اضافى نمىباشد. همجنين، سموم نانو سيلور و نانو مس تأثير قارجكى بيشترى نسبت به سموم رايج و قديمى دارند (مصطفوى نيشابورى و نصرالهنزاد بوسا). به علاوه، طبق مطالعهى توتيدا و همكاران (Tutida et al. 2007) شيوع و شدت بيمارى لكه غربالى در باغهاى آلو با افزايش كاربرد نيتروزن افزايش يافته و يتاسيه به دليل موجود بودن آن در خاك يا بقاياى گياهى، تأثيرى در شيوع و شدت بيمارى 


\section{نتيجهَيرى و يِيشنهاد}

لكه غربالى ناشى از قارج Stigmina carpophila يكى از مهمترين و خسارتزاترين بيمارىهاى درختان

ميوه هستهدار در اغلب مناطق جهان و ايران محسوب مىشود. دامنهى ميزبانى قارج بيمارگر وسيع بوده و تقريباً به تمامى گونههاى مختلف درختان ميوه هستهدار حمله مىكند. براى مديريت بيمارى تلفيقى از روشهاى زراعى، استفاده از ارقام مقاوم و سمياشى با سموم محافظتى و يا نفوذى يِينهاد مىشود.

\section{References}

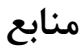

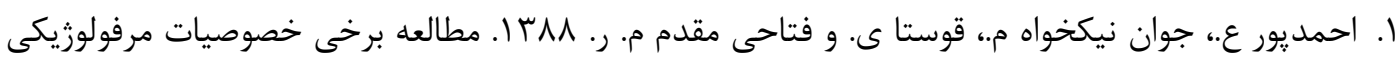

و بيولوزيكى Wilsonomyces carpophila در استان آذربايجان غربى. رستنىها • 1: 9 • 1-19.

ז. احمديور ع.، قوستا ى، جوان نيكخواه م.، فتاحى مقدم م. ر. و غضنفرى ك. • وبا. مطالعه تخصص يافتكى

و دامنه ميزبانى Wilsonomyces carpophila، عامل لكه غربالى درختان ميوه هستهدار و ارزيابى

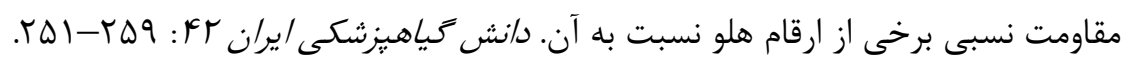

ז. برازنده آق كاريز ر.، ينجهكه ن،، حاجيان شهرى م.، صباغ س. ك. و بهزادى م. و9؟ا. بررسى تنوع زنتيكى

Wilsonomyces carpophila

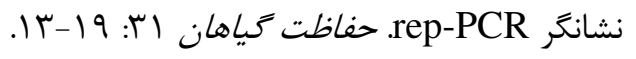

f. . حاجيان شهرى م.، كنجى مقدم ا. و كريمى شهرى م. ر. سوس ا. ارزيابى مقاومت نسبى برخى ارقام زردآلو به

بيماركر Wilsonomyces carpophila عامل بيمارى غربالى درختان ميوه هستهدار. حفاظت كياهان

$$
.9 \Lambda-1 \cdot 0: r \wedge
$$

ه. خباز جلفايى ح.، ذاكر م.، كشاورز ك. و عظيمى ش. بوسبا. ارزيابى كارآيى مخلوط بردو (SC 18\%) در كنترل بيمارى غربالى زردآلو با عامل Wilsonomyces carpophila. آفت كشها در علوم كياهبرشكى ז:

$$
.1 \cdot-1 \cdot 1
$$

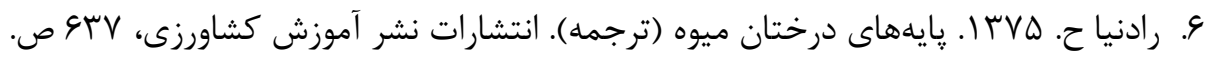


V. سرابى ا.، جوان نيكخواه م.، فتاحى مقدم م. ر.، قوستا ى. و احمديور ع. זوسا. ساختار زنتيكى

جمعيتهاى Wilsonomyces carpophila در استان آذربايجان غربى. اولين كنگره قارج شناسى ايران،

$$
\begin{aligned}
& \text { رشت. ص •19. }
\end{aligned}
$$

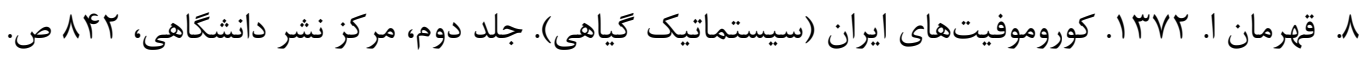

$$
\begin{aligned}
& \text { 9. مصطفوى نيشابورى ف. س. و نصرالهنزاد س. بوسا. مقايسه تأثير دو سم نانو با سموم رايج در كنترل }
\end{aligned}
$$

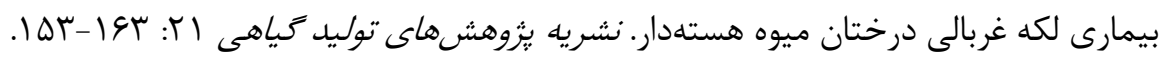

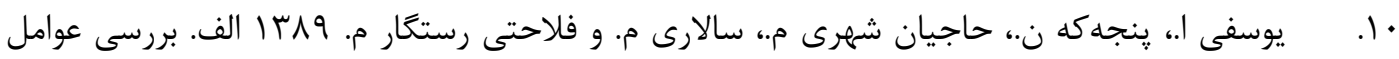

$$
\begin{aligned}
& \text { قارجى مولد بيمارى غربالى در درختان ميوه هستهدار در استان خراسان رضوى. حفاظت حياهان F؟T: } \\
& .110-111
\end{aligned}
$$

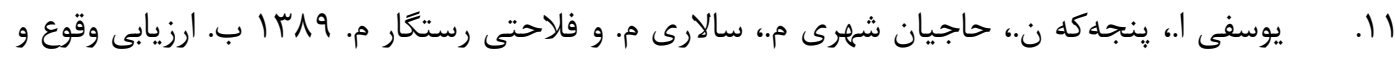

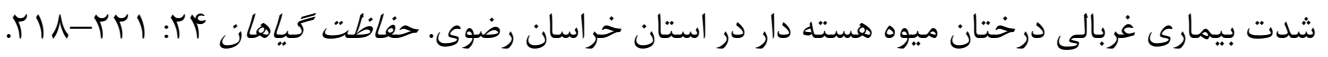

12. Adaskaveg J. E. 1995. Conidial morphology, host colonization and development of shot hole of almond caused by Wilsonomyces carpophila. Canadian Journal of Botany 73:432-444.

13. Adaskaveg J. E., Ogawa J. M. and Butler E. E. 1990. Morphology and ontogeny of conidia in Stigmina carpophila, causal pathogen of shot hole disease of Prunus species. Mycotaxon 37:275-290.

14. Ahmadpour A., Ghosta Y., Javan-Nikkhah M., Fatahi R. and Ghazanfari K. 2009. Isolation and pathogenicity tests of Iranian cultures of the shot hole pathogen of Prunus species, Wilsonomyces carpophila. Australasian Plant Disease Notes 4:133134.

15. Ahmadpour A., Ghosta Y., Javan-Nikkhah M., Ghazanfari K. and Fatahi M. R. 2012. Study on morphology, pathogenicity and genetic diversity of Wilsonomyces carpophila isolates, the causal agent of shot hole of stone fruit trees based on RAPDPCR in Iran. Archives of Phytopathology and Plant Protection 45:2076-2086.

16. Ayub R. A., Assunção M. and Torres A. L. 2013. Reaction of genotypes of the nectarine (Prunus persica var. nucipersica) to leaf rust and shot hole, and the development of defoliation. Revista Ciência Agronômica 44:398-403. 
17. Bubici G., D'Amico M. and Cirulli M. 2010. Field reactions of plum cultivars to the shot-hole disease in southern Italy. Crop Protection 29:1396-1400.

18. García-Galavís P. A., Santamaría C., Jiménez-Bocanegra J. A., Casanova L. and Daza A. 2009. Susceptibility of several Japanese plum cultivars to pests and diseases in a newly established organic orchard. Scientia Horticulturae 123:210-216.

19. Grantina-Ievina L. and Stanke L. 2015. Incidence and severity of leaf and fruit diseases of plums in Latvia. Communications in Agricultural and Applied Biological Sciences 80:421-433.

20. Grove G. G. 2002. Influence of temperature and wetness period on infection of cherry and peach foliage by Wilsonomyces carpophila. Canadian Journal of Plant Pathology 24:40-45.

21. Highberg L. M. and Ogawa J. M. 1986a. Yield reduction in almond related to incidence of shot-hole disease. Plant Disease 70:825-828.

22. Highberg L. M. and Ogawa J. M. 1986b. Survival of shot hole inoculum in association with dormant almond buds. Plant Disease 70:828-831.

23. Ivanová H., Kaločaiová M. and Bolvanský M. 2012. Shot-hole disease on Prunus persica - the morphology and biology of Stigmina carpophila. Folia Oecologica 39:21-27.

24. Marcuzzo L. L., Santos J. E., Marcuzzo L. L. and Santos J. E. 2017. Temporal progress of shot hole in different peach genotypes. Summa Phytopathologica 43:239242.

25. Marin-Felix Y., Groenewald J. Z., Cai L., Chen Q., Marincowitz S., Barnes I., Bensch K., Braun U., Camporesi E., Damm U., de Beer Z. W., Dissanayake A., Edwards J., Giraldo A., Hernández-Restrepo M., Hyde K. D., Jayawardena R. S., Lombard L., Luangsa-Ard J., McTaggart A. R., Rossman A. Y., Sandoval-Denis M., Shen M., Shivas R. G., Tan Y.P., van der Linde E.J., Wingfield M. J., Wood A. R., Zhang J. Q., Zhang Y. and Crous P. W. 2017. Genera of phytopathogenic fungi: GOPHY 1. Studies in Mycology 86:99-216.

26. McDonald B. A. 1997. The population genetics of fungi: Tools and Techniques. Phytopathology 87:448-453.

27. Milgroom M. G. 2015. Population Biology of Plant Pathogens: Genetics, Ecology, and Evolution. APS Press, Minnesota, USA, 399p. 
28. Nabi A., Shah M. U. D., Padder B. A., Dar M. S. and Ahmad M. 2018. Morphocultural, pathological and molecular variability in Thyrostroma carpophilum causing shot hole of stone fruits in India. European Journal of Plant Pathology (In press).

29. Ogawa J. M., Zehr E. I., Bird G. W., Ritchie D. F., Uriu K. and Uyemoto J. K. 1995. Compendium of Stone Fruit Diseases. APS Press, Minnesota, USA, 98p.

30. Romanazzi G., Murolo S. and Branzanti B. 2005. Resistance of sweet cherry to Coryneum and cherry leaf spot. Phytopathology 95:S90.

31. Shaw D. A., Adaskaveg J. E. and Ogawa J. M. 1990. Influence of wetness period and temperature on infection and development of shot hole disease of almond caused by Wilsonomyces carpophila. Phytopathology 80:749-756.

32. Teviotdale B. L., Goodell N. and Harper D. 1997. Abscission and kernel quality of almond fruit inoculated with the shot hole pathogen Wilsonomyces carpophila. Plant Disease 81:1454-1458.

33. Tovar-Pedraza J. M., Ayala-Escobar V. and Segura-León O. L. 2013. Thyrostroma carpophilum causing apricot shot-hole in Mexico. Australasian Plant Disease Notes 8:31-33.

34. Tutida I., Mio L. L. M. D. and Motta A. C. V. 2007. Incidence and severity of shot hole in plum's leaves related in to nitrogen and potassium doses. Ciência Rural 37:1227-1234.

35. Yousefi A. and Hajian Shahri M. 2014. Shot hole disease, survival and pathogenicity of the causal agent on stone fruit trees in Northeast Iran. Journal Crop Protection 3:563-571. 